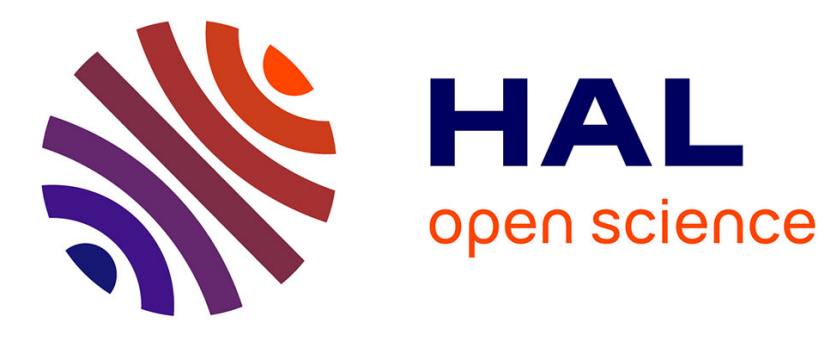

\title{
Porphyrin-based hybrid silica-titania as visible-light photocatalyst
}

Julien G Mahy, Carlos A Paez, Carole Carcel, Catherine Bied, Andrew S Tatton, Christian Damblon, Benoît Heinrichs, Michel Wong Chi Man, Stéphanie D Lambert

\section{To cite this version:}

Julien G Mahy, Carlos A Paez, Carole Carcel, Catherine Bied, Andrew S Tatton, et al.. Porphyrinbased hybrid silica-titania as visible-light photocatalyst. Journal of Photochemistry and Photobiology A: Chemistry, 2019, 373, pp.66-76. 10.1016/j.jphotochem.2019.01.001 . hal-03096440

\section{HAL Id: hal-03096440 https://hal.science/hal-03096440}

Submitted on 5 Jan 2021

HAL is a multi-disciplinary open access archive for the deposit and dissemination of scientific research documents, whether they are published or not. The documents may come from teaching and research institutions in France or abroad, or from public or private research centers.
L'archive ouverte pluridisciplinaire HAL, est destinée au dépôt et à la diffusion de documents scientifiques de niveau recherche, publiés ou non, émanant des établissements d'enseignement et de recherche français ou étrangers, des laboratoires publics ou privés. 


\title{
Porphyrin-based hybrid silica-titania as visible-light photocatalyst
}

\author{
Julien G. Mahy ${ }^{\mathbf{a}^{*}}$, Carlos A. Paez ${ }^{\mathrm{a}}$, Carole Carcel ${ }^{\mathrm{b}}$, Catherine Bied ${ }^{\mathrm{b}}$, Andrew S. Tatton ${ }^{\mathrm{c}}$, Christian \\ Damblon ${ }^{\mathrm{c}}$, Benoît Heinrichs ${ }^{\mathrm{a}}$, Michel Wong Chi Man ${ }^{\mathrm{b}}$, Stéphanie D. Lambert ${ }^{\mathrm{a}}$ \\ ${ }^{a}$ Department of Chemical Engineering - Nanomaterials, Catalysis \& Electrochemistry, University of \\ Liège, B6a, Quartier Agora, Allée du six Août 11, 4000 Liège, Belgium \\ ${ }^{b}$ Institut Charles Gerhardt Montpellier, UMR-5253, ENSCM, Université Montpellier, CNRS, 8 Rue de \\ l'École Normale, 34296 Montpellier, France \\ ${ }^{c}$ Structural Biological Chemistry Laboratory, University of Liege, Liège, Belgium
}

Keywords: Sol-Gel process; photocatalysis; bridged silsesquioxanes; $p$-nitrophenol degradation; hybrid silica-titania

\begin{abstract}
A silylated porphyrin derivative is co-hydrolyzed with $\mathrm{Ti}(\mathrm{OiPr})_{4}$ to produce a hybrid $\mathrm{TiO}_{2}$ photocatalyst, and three different ratios between porphyrin and $\mathrm{TiO}_{2}$ are made. In this way, the porphyrin fragments are held in the resulting matrix through strong Si-O-Ti covalent bonds to limit porphyrin leaching. Thanks to its photoactive character the porphyrin fragment can act as an actuator for the $\mathrm{TiO}_{2}$ to degrade organic pollutants using light from ultra-violet to the visible range. The photocatalysts are synthesized using an easy aqueous route allowing "green conditions" for synthesis. For comparative purposes, the corresponding pure $\mathrm{TiO}_{2}$ and a grafted catalyst are also synthesized and studied. For all samples, a mixture of anatase/brookite $\mathrm{TiO}_{2}$ is obtained, resulting in crystalline materials with low temperature synthesis. The three porphyrin-doped samples prepared in water prove to be efficient photocatalysts for the degradation of $p$-nitrophenol (PNP) under visible light, and an improvement in photoactivity is observed when the amount of porphyrin increases. The photocatalyst activity is very stable over time as the PNP degradation remains nearly constant after $264 \mathrm{~h}$ of testing, showing no leaching of porphyrin. In recycling tests, the grafted sample presents bond breaking between $\mathrm{POR}-\mathrm{Si}$ and $\mathrm{TiO}_{2}$ and a decrease in photoactivity towards pure $\mathrm{TiO}_{2}$ sample activity. A comparison with the commercial Evonik P25 catalyst shows that the porphyrin-doped $\mathrm{TiO}_{2}$ is nearly 6 times more photoactive under visible light for PNP degradation.
\end{abstract}

\section{Introduction}

Environmental protection has become a major issue for our planet and this increases the urgency of finding and designing innovative materials that can limit and minimize environmental pollution. In this context, heterogeneous photocatalysis based on the illumination of semiconductor oxides $\left(\mathrm{TiO}_{2}, \mathrm{ZnO}, \mathrm{SnO}_{2}\right)$ or chalcogenides $(\mathrm{CdS}, \mathrm{ZnS})$ is a subject that has been widely studied for decades [1-4] and is a rapidly developing area of research with high potential for industrial applications [5], mainly in the case of $\mathrm{TiO}_{2}$ [6-8] such as dye-sensitized solar cells [9], electrochromic displays [10] and lithium-ion batteries [11]. As has been explained previously, when the semiconductor oxide is illuminated by photons of energy $(\mathrm{h} v)$ at or above the energy of the band gap $(E \mathrm{~g})$, there is absorption of photons and creation of electron-hole pairs in the solid materials [6-8] which can degrade organic pollutants $[5,7,8,12-14]$.

$\mathrm{TiO}_{2}$ was first reported to be an efficient photocatalyst for water splitting to produce hydrogen [15] and is the most prevalent photocatalyst that is used to decompose organic pollutants $[6,12,14,16,17]$. It represents a promising candidate photocatalyst thanks to its chemical inertness, non-toxicity, photostability and costeffectiveness [18,19]. Moreover it can be carefully designed for many other applications [20]. A Sol-Gel process is commonly used to prepare $\mathrm{TiO}_{2}$ in the form of a powder or film under mild synthesis conditions, and thus the anatase phase is selectively prepared, rather than the rutile phase [13,21-25]. It is well-known that the anatase phase has a higher activity than the rutile phase [26]. Anatase $\mathrm{TiO}_{2}$ has a band 
gap energy, $E \mathrm{~g}$, equal to $3.2 \mathrm{eV}$, and when it is illuminated electrons are photo-induced from the valence band to the conduction band if the radiation has a wavelength $\lambda<387 \mathrm{~nm}$, which corresponds to UVeA radiation. However, when illuminated by solar light only a small portion of the radiation (2 to 3\%) is used for activation [27]. For economic and ecological reasons much effort is being devoted to developing the efficient use of solar light, targeting an increase in the sensitivity of $\mathrm{TiO}_{2}$ to visible light [28-30].

In numerous investigations various metals [1,22,28,31-33], alone or in combination with other semiconductors [34] and non-metallic elements [28,35-37], have been used to activate $\mathrm{TiO}_{2}$ with visible light. For example, $\mathrm{N}$-doped $\mathrm{TiO}_{2}$ has been investigated and was shown to be significantly and photocatalytically active under visible light [35,38]. Moreover, dye photosensitization [39-41] in particular has been used to dope $\mathrm{TiO}_{2}$ with photosensitive molecules such as porphyrins $[40,41]$. Porphyrins are photoactive compounds which are excited by the absorption of visible light causing the transfer of an electron from the HOMO (Highest Occupied Molecular Orbital) level to the LUMO level (Lowest Unoccupied Molecular Orbital). Photosensitization of $\mathrm{TiO}_{2}$ results from the transfer of a photo-induced electron of the LUMO level of the porphyrin into the conduction band of $\mathrm{TiO}_{2}$ [42-44]. Electrons of the $\mathrm{TiO}_{2}$ conduction band react with electron-accepting molecules such as $\mathrm{O}_{2}$. In the last couple of years, porphyrin derivatives have been explored for several fields. When incorporated into hybrid silica nanoparticles and complexed with Zn, they have been used as 2-photon photosensitizers for biomedical applications (imaging, drug delivery and particle degradation) $[45,46]$. They have also been used as photocatalysts [47] and electrocatalysts [48]. When complexed with $\mathrm{Fe}(\mathrm{III})$ ions, porphyrins could catalyze the epoxidation of cyclooctene and also the hydroxylation of alkanes with iodosobenzene (PhIO) [49].

Typically, 5,10,15,20-tetrakis[ $p$-(carboxy)phenyl]porphyrin (TCPP), which is composed of a porphyrin core and four meso-carboxyphenyl groups $\left(\mathrm{C}^{2} \mathrm{H} 5 \mathrm{COO}^{-}\right)$, is often used as a $\mathrm{TiO}_{2}$ photosensitizer $[42,50,51]$ and is commonly grafted onto the surface of the $\mathrm{TiO}_{2}$ particles via carboxylic groups. In the case of photocatalytic applications in aqueous media this sort of grafting method is not appropriate as the acidic or basic media may cause the cleavage of Ti-O-C bonds, leading to the desorption and leaching of TCPP from the $\mathrm{TiO}_{2}$ matrix [52].

One way to overcome this drawback consists of binding $\mathrm{TiO}_{2}$ to organics through strong covalent Ti-O-Si bonds. There are two approaches to achieve this: a cogelation of a $\mathrm{TiO}_{2}$ source with an organosilane, or by grafting the latter onto the surface of $\mathrm{TiO}_{2}$. Many commercial organotrialkoxysilanes are available and a coupling silane such as APTES (3aminopropyltriethoxysilane) is easily grafted onto $\mathrm{TiO}_{2}$ allowing it, for example, to bind biological substrates. This was demonstrated by the stepwise post-grafting of Streptavidin to Biotin/APTES-grafted $\mathrm{TiO}_{2}$ [53]. Besides the APTES-derived materials, several organosilanes were also designed for cogelation with $\mathrm{TiO}_{2}$. Recently P-doping based hybrid materials were reported to be efficient UV-vis photocatalysts [54,55] which when complexed with silver ions significantly increased the photocatalytic degradation of organic pollutants [29].

In this context, appropriately designed photoactive organoalkoxysilanes like silylated porphyrins can be used for sol-gel cogelation with titanium alkoxide to generate Ti-O-Si bonds which will hold the porphyrin fragment more tightly than the Ti-O-C bonds of TCPP grafted onto the surface of $\mathrm{TiO}_{2}$ [52].

In this work we, for the first time, explore the possibility of covalently binding $\mathrm{TiO}_{2}$ to a silylated porphyrin, 5,10,15,20-tetrakis[p-(3-Ntriethoxysilylpropylureido) phenyl]porphyrin (POR-Si), with the aim of sensitizing $\mathrm{TiO}_{2}$ to low energy light. The materials are synthesized by cogelification of POR-Si with Titanium IV Tetraisopropoxide, $\mathrm{Ti}(\mathrm{O}-\mathrm{iPr})_{4}$ (TTIP) and are produced following an aqueous synthetic route. Three molar ratios between porphyrin and $\mathrm{TiO}_{2}$ will be assessed. A grafted sample, as is the case in most porphyrin-doped catalysts in the literature [50,56-60], is also synthesized for comparisons of activity and durability. The 
performance of these materials is assessed for the degradation of p-nitrophenol (PNP, $\mathrm{C}_{6} \mathrm{H}_{5} \mathrm{NO}_{3}$ ) under $\mathrm{UV} /$ visible light and low energy light. The corresponding porphyrin-free $\mathrm{TiO}_{2}$ materials are also synthesized and tested for comparison. A comparison with commercial Evonik P25 will be made, as is a stability study of the catalyst photoactivity over $264 \mathrm{~h}$ of operation.

\section{Materials and methods}

\subsection{Synthesis of silylated porphyrin material}

The synthesis of 5,10,15,20-tetrakis[ $p$-(3- $N$-triethoxysilylpropylureido)-phenyl]porphyrin $(\mathrm{POR}-\mathrm{Si})$ is made following published methods $[61,62]$ in three steps represented in Fig. 1. The complete synthesis protocol is described in Supplementary Materials.

\subsection{Synthesis of pure and porphyrin-based $\mathrm{TiO}_{2}$ materials}

The process used for the cogelification of $\mathrm{TiO}_{2}$ with POR-Si is an aqueous route using mostly water as solvent. The doping molar ratios, ${ }^{n} \mathrm{POR}-\mathrm{Si} /{ }^{n} \mathrm{TiO}_{2}$, are equal to $0.001,0.003$ and 0.006 , with ${ }^{n} P O R-S i$ representing the molar amount of POR-Si (mol) in the sample and $n T i O_{2}$, corresponding to the molar amount of $\mathrm{TiO}_{2}(\mathrm{~mol})$ in the sample. For comparison, the corresponding blank $\mathrm{TiO}_{2}$ material with no POR-Si is also synthesized in the same conditions and is called pure $\mathrm{TiO}_{2}$. For comparison with other works [50,56-60], a grafted sample is also synthesized with a doping molar ratio of 0.006 . When required, experiments are carried out with standard high vacuum and Schlenk techniques under a $\mathrm{N}_{2}$ atmosphere using dry solvents which are degassed and cannula- or syringe-transferred.

Pure and POR-Si $\mathrm{TiO}_{2}$ samples are synthesized using titanium (IV) tetraisopropoxide (TTIP, $>97 \%$, Sigma-Aldrich), nitric acid $\left(\mathrm{HNO}_{3}, 65 \%\right.$, Merck), isopropanol ( $i$-PrOH, $99.5 \%$, Acros Organics), POR-Si and distilled water as starting materials.

\subsubsection{Pure $\mathrm{TiO}_{2}$}

Distilled water $(50 \mathrm{~mL})$ is acidified with HNO3 to $p H=1$. In another vessel, TTIP (7 $\mathrm{mL})$ is mixed with $i-\mathrm{PrOH}(3 \mathrm{~mL})$, and the solution is stirred at room temperature for $30 \mathrm{~min}$ [14]. The mixture produced is added to the acidified water under vigorous stirring and maintained for $4 \mathrm{~h}$ at a temperature of $80^{\circ} \mathrm{C}$ [14]. A light blue transparent liquid sol is obtained, which is dried under an ambient air flow to obtain a xerogel [14]. The xerogel is crushed to give a white-yellow powder of $\mathrm{TiO}_{2}$ catalyst [14]. The powder is dried at $100{ }^{\circ} \mathrm{C}$ for $1 \mathrm{~h}$.

\subsubsection{Doped $\mathrm{TiO}_{2}\left(\mathrm{TiO}_{2} / \mathrm{Px}\right.$ samples)}

The same procedure as for pure $\mathrm{TiO}_{2}$ is used, except that POR-Si $(59.15,118.3 \mathrm{mg}$ or $236.6 \mathrm{mg}$ depending the molar ratio) is added to the "TTIP $+i$-PrOH" mixture. After stirring, this mixture is added to acidified water. After reaction time, a dark liquid sol is obtained and dried under an ambient air flow to obtain a xerogel, which is crushed resulting in a violet powder of POR-Si covalently bonded to the $\mathrm{TiO}_{2}$ catalyst. The powder is dried at $100{ }^{\circ} \mathrm{C}$ for $1 \mathrm{~h}$. The doped samples are named $\mathrm{TiO}_{2} / \mathrm{Px}$ where $\mathrm{x}$ is equal to 1,3 or 6 , in reference to the doping molar ratio values $(0.001,0.003$ or 0.006$)$. The amount of dopant remains low in order to limit the cost of the catalyst.

\subsubsection{Grafted sample}

For POR-Si grafted TiO2 [50,56-60], $1 \mathrm{~g}$ of pure $\mathrm{TiO}_{2}$ is mixed with $125 \mathrm{mg}$ of POR-Si in 500 $\mathrm{mL}$ of ethanol (EtOH, Merck,>99\%). The mixture is stirred for $48 \mathrm{~h}$, then the suspension is 
centrifuged at $10000 \mathrm{rpm}$ for $10 \mathrm{~min}$. The sample is washed in $50 \mathrm{~mL}$ of EtOH then in $50 \mathrm{~mL}$ of ultra-pure water. The sample is dried under an ambient air flow to obtain a xerogel, which is crushed resulting in a green powder. The obtained sample is denoted as TiO2/P6-Grafted.

\subsection{Sample characterization}

${ }^{1} \mathrm{H},{ }^{13} \mathrm{C}$ and ${ }^{29} \mathrm{Si}$ NMR in solution are recorded on a Bruker instrument (AVANCE-III 400) and are referenced to solvent signals (DMSO $d_{6}: \delta=2.50 \mathrm{ppm}$ ). ${ }^{29} \mathrm{Si}$ solid state NMR spectra are obtained from a Bruker Avance I spectrometer at an operating $1 \mathrm{H}$ Larmor frequency of 400.13 $\mathrm{MHz}(\mathrm{B} 0=9.4 \mathrm{~T})$, corresponding to a ${ }^{29} \mathrm{Si}$ Larmor frequency of $79.49 \mathrm{MHz}$. All experiments are obtained using a Bruker HXY $4 \mathrm{~mm}$ probe operating in double resonance mode, and at a MAS frequency of $10 \mathrm{kHz} .{ }^{29} \mathrm{Si}$ cross-polarisation experiments are performed using a ramped-contact (50\% to $100 \%$ amplitude) for a duration of $5 \mathrm{~ms}$, and a recycle delay of $1 \mathrm{~s}$.

Nitrogen adsorption-desorption isotherms are measured at $77 \mathrm{~K}$ using a Micromeritics ASAP 2420 analyzer, after outgassing for $24 \mathrm{~h}$ at room temperature, and provide the specific surface area by the BET method, SBET, and the specific micropore volume is calculated using Dubinin-Radushkevich theory, VDR [63].

X-ray diffraction patterns are recorded with a Siemens D5000 powder diffractometer $\left(\mathrm{Cu}-\mathrm{K} \alpha\right.$ radiation). The size of the $\mathrm{TiO}_{2}$ crystallites, $d \mathrm{XRD}$, is calculated from XRD measurements by the Scherrer equation (Eq. (1)) [14]:

$d_{X R D}=0,91(\lambda / B \cos \theta)$

where $B$ is the full-width at half-maximum of the peak after correction of the instrumental broadening ( $\mathrm{rad}), \lambda$ is the wavelength $(\mathrm{nm})$ and $\theta$ is the Bragg angle (rad) $[27,64]$.

The repartition of the crystallographic phases is estimated with the Rietveld method using "Profex" software [65]. The amount of crystalline phase is estimated using a $\mathrm{CaF}_{2}$ internal standard (calcium fluoride, Sigma-Aldrich, anhydrous powder, 99.99\% trace metal basis) also using "Profex" software [66].

The sample optical properties are evaluated using diffuse reflectance spectroscopy measurements in the region of 300-800 nm with a Varian Cary 500 UV-Vis-NIR spectrophotometer, equipped with an integrating sphere (Varian External DRA-2500) and using $\mathrm{BaSO}_{4}$ as reference [67]. The $\mathrm{UV}-\mathrm{V}$ is spectra recorded in diffuse reflectance $\left(R_{\text {sample }}\right)$ mode are transformed by using the Kubelka-Munk function (Eq. (2)):

$F(R \infty)=(1-R \infty)^{2} / 2 R \infty$

where $R \infty$ is defined as $R \infty=R$ sample/Rreference [27,67-69], with $R_{\text {reference }}$ the diffuse reflectance measured for the $\mathrm{BaSO}_{4}$ reference. To compare to each other, all spectra are normalized to 1.0 by dividing each spectrum by its maximum intensity [27,70]. Using the wellknown equation (Eq. (3)):

$(F(R \infty) \mathrm{h} v)^{1 / m}=C\left(\mathrm{~h} v-E_{\mathrm{g}}\right)$

where $\mathrm{C}$ and $\mathrm{m}$ are constants, which depend on the optical transitionmode. The direct and indirect optical band-gap values $E_{\mathrm{g}}$,direct $(\mathrm{eV})$ and $E_{\mathrm{g}}$,indirect $(\mathrm{eV})$ are obtained by plotting, respectively, $(\mathrm{F}(R \infty) \mathrm{h} v)^{2}$ and $(\mathrm{F}(R \infty) \mathrm{h} v)^{1 / 2}$ as a function of the photon energy $\mathrm{h} v$ and by determining the intersection of the linear part of the curve and the $\mathrm{x}$-axis $[27,67,71]$.

The UV/vis spectrum of the ethanolic solution of POR-Si is obtained using a Genesys $10 \mathrm{~S} \mathrm{UV/vis} \mathrm{(Thermo} \mathrm{Scientific).} \mathrm{Fourier} \mathrm{transform} \mathrm{infrared} \mathrm{(FT-IR)} \mathrm{spectra} \mathrm{in} \mathrm{the} \mathrm{region} \mathrm{of}$ 
500-4000 $\mathrm{cm}^{-1}$ are recorded at room temperature with a Spectrum Equinox 55 from Bruker. All catalyst powders are dispersed in $\mathrm{KBr}$ (1 wt \% for all samples).

\subsection{Photocatalytic tests}

The photocatalytic activity of all the samples is evaluated by monitoring the degradation of $p$ nitrophenol (PNP) after 0, 5, 8 and $24 \mathrm{~h}$, in triplicate. For each test, the degradation percentage of PNP, DPNPi, is evaluated following Eq. (4) [14,67] :

$D_{P N P i}(\%)=\left(1-[P N P]_{\mathrm{i}} /[P N P]_{0}\right) * 100$

where $[\mathrm{PNP}]_{\mathrm{i}}$ represents the residual concentration of PNP at time $t=\mathrm{i}$ h and $[\mathrm{PNP}]_{0}$ represents the initial concentration of PNP at time $t=0 \mathrm{~h}$.

The experimental procedures are performed similarly to those of reported literature [27,72]. The residual concentration of PNP is measured by UV/Vis spectroscopy (GENESYS 10S UV-Vis from Thermo Scientific) at $318 \mathrm{~nm}$. Each synthesis is made three times and, for each of these three syntheses, three flasks with catalyst are exposed to light to calculate the PNP degradation (nine PNP degradation tests measured overall), one is exposed to light without catalyst to evaluate PNP natural decomposition under UV/visible light and one is kept in the dark to evaluate PNP adsorption on the catalyst [14,67]. In each flask, the initial concentrations of catalyst (if present) and PNP are equal to $1 \mathrm{~g} \mathrm{~L}^{-1}$ and $10^{-4} \mathrm{M}$ respectively. Experiments are conducted in test tubes fitted with a sealing cap $[14,67]$. These tubes are placed in a cylindrical glass reactor with a halogen lamp in the center. The halogen lamp has a continuous spectrum from 300 to $800 \mathrm{~nm}(300 \mathrm{~W}, 220 \mathrm{~V})$, which is measured with a Mini-Spectrometer TM-UV/vis C10082MD from Hamamatsu [14,67]. The reactor is maintained at a constant temperature

$\left(20^{\circ} \mathrm{C}\right)$ by a cooling system, operating with recirculating water. The lamp is cooled by a similar system. Aluminum foil covers the outer wall of the reactor to prevent any interactions with the room lighting $[14,67]$. The volume of each flask is equal to $10 \mathrm{~mL}$, stirred by a magnetic stirrer. Each catalyst is tested under UV/visible light (the halogen lamp) and under low energy light (the halogen lamp is covered by an UV filter, which removes the wavelengths $<390 \mathrm{~nm}$ ) $[14,67]$. Commercial Evonik P25 catalyst is also assessed as reference material for comparison.

\subsection{Durability study}

To test the stability of the photoactivity of samples and the stability of the porphyrin, photocatalytic recycling tests are made on all samples under UV/visible light and under visible light. The same protocol as explained in the above paragraph (Section 2.4) is performed on all catalysts. After this, the samples are recovered by centrifugation (10 $000 \mathrm{rpm}$ for $1 \mathrm{~h}$ ) followed by drying at $120{ }^{\circ} \mathrm{C}$ for $24 \mathrm{~h}$. A total of 10 photocatalytic tests as described above are applied to the re-used catalysts. So, each tested catalyst undergoes eleven catalytic tests ( $264 \mathrm{~h}$ of operation), and a mean PNP degradation over the three recycling tests is then calculated.

For the highest porphyrin-loaded sample $\left(\mathrm{TiO}_{2} / \mathrm{P} 6\right)$, after the eleven photocatalytic cycles the recovered catalyst is characterized by diffuse reflectance spectroscopy measurement and ${ }^{29} \mathrm{Si}$ NMR to check that porphyrin is still present. A macroscopic observation of the color of the photocatalyst samples is also made to ensure that no discoloration happens.

\section{Results and discussion}

\subsection{Syntheses of silylated porphyrin}


5,10,15,20-tetrakis[ $p$-(3- $N$-triethoxysilylpropylureido)phenyl]-porphyrin (POR-Si) is synthesized in three steps (Fig. 1) starting from the synthesis of POR-NO $\mathrm{N}_{2}$ which is obtained from pyrrole and $p$-nitroformaldehyde at a $17 \%$ yield. The transformation of $\mathrm{POR}-\mathrm{NO}_{2}$ into POR-NH $\mathrm{N}_{2}$ is obtained by reduction with tin(II) chloride in water and concentrated $\mathrm{HCl}$ (yield: $31 \%)$. Reaction of the aminoporphyrine $\left(\mathrm{PORNH}_{2}\right)$ with 3-isocyanatopropyltriethoxysilane produces POR-Si (69\%).
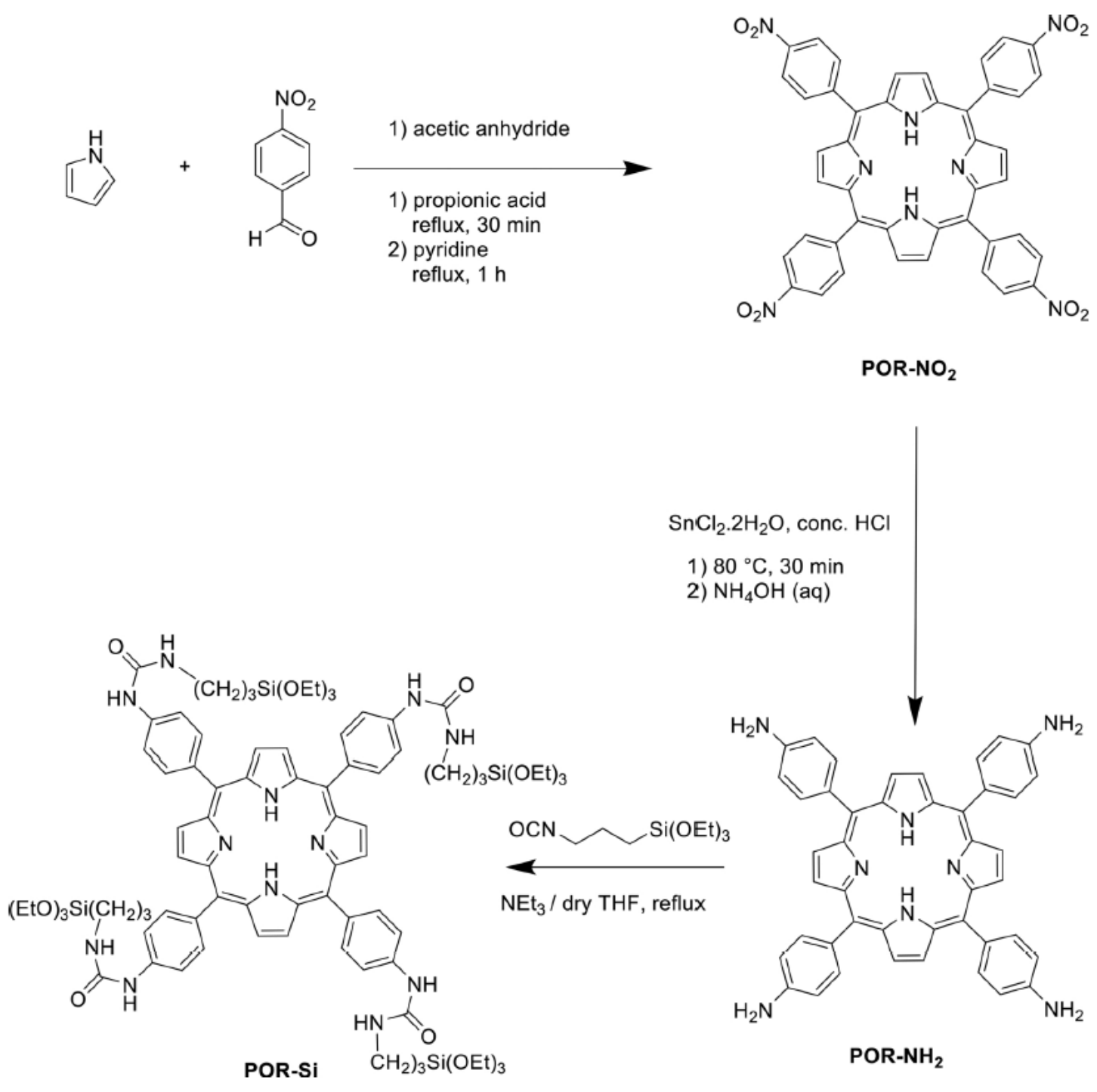

Fig. 1. Synthesis of POR-Si in three steps. More information on the synthesis in Supplementary Materials.

\subsection{Synthesis and characterization of the materials}

Five materials are prepared by the sol-gel process following the aqueous procedure as described above in section 2.2.: one pure $\mathrm{TiO}_{2}$, three porphyrin-doped $\mathrm{TiO}_{2}$ samples $\left(\mathrm{TiO}_{2} / \mathrm{P} 1\right.$, $\mathrm{TiO}_{2} / \mathrm{P} 3$ and $\left.\mathrm{TiO}_{2} / \mathrm{P} 6\right)$ and one material obtained by grafting POR-Si onto pure $\mathrm{TiO}_{2}\left(\mathrm{TiO}_{2} / \mathrm{P} 6-\right.$ Grafted).

\subsubsection{X-ray diffraction of the powdered materials}

X-ray diffraction patterns of the five materials together with anatase (A) and brookite (B) diffractograms are presented in Fig. 2. 


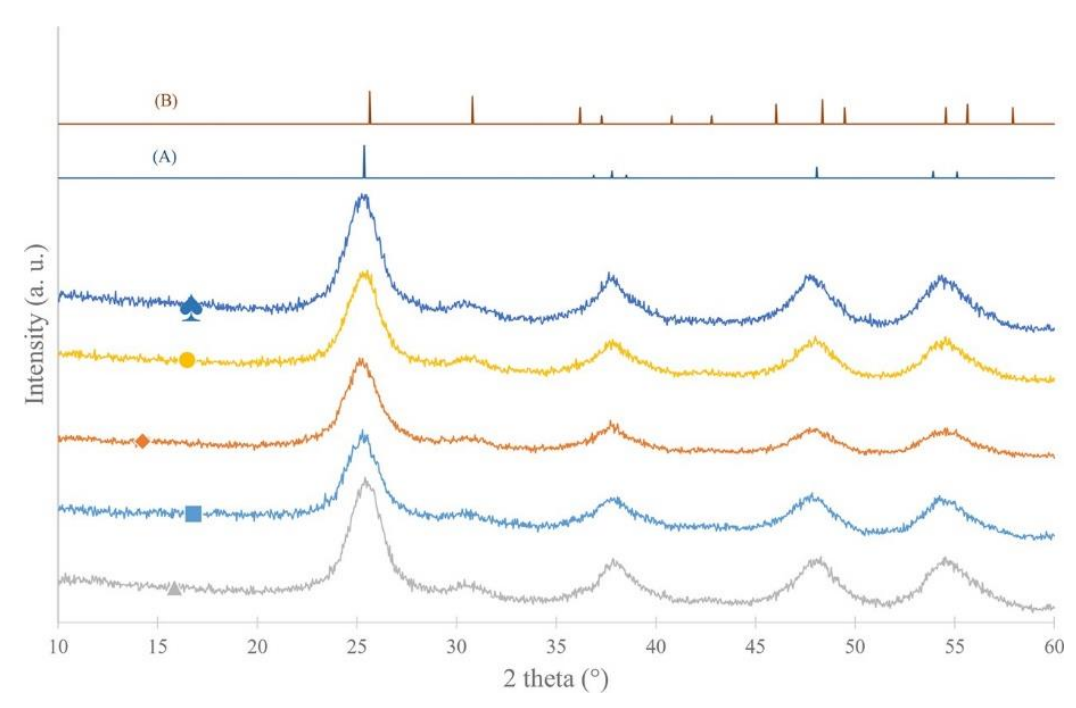

Fig. 2. XRD patterns of pure $\mathrm{TiO}_{2}(\boldsymbol{\Delta}), \mathrm{TiO}_{2} / \mathrm{P} 1(\bullet), \mathrm{TiO}_{2} / \mathrm{P} 3(\bullet), \mathrm{TiO}_{2} / \mathrm{P} 6(\bullet)$ and $\mathrm{TiO}_{2} / \mathrm{P} 6-G r a f t e d(\bullet)$ samples, (A) reference pattern of anatase and (B) reference pattern of brookite.

Of the five materials, it appears that all samples present crystalline $\mathrm{TiO}_{2}$ materials as diffractograms exhibit anatase and brookite peaks. The addition of POR-Si has no influence on the crystallinity of the resulting $\mathrm{TiO}_{2}$ materials as all patterns are quite similar. An estimation of the phase repartition is made with Profex software [65] and calibration with $\mathrm{CaF}_{2}$ to obtain the crystalline and amorphous fraction [66], all the results are depicted in Table 1 ; in each aqueous material synthesis, approximately the same (distribution value $\pm 5 \%$ ) phase repartition is observed: the anatase phase is the main crystalline phase corresponding to $65-70 \%$ of the samples, the brookite phase amount is around 5\% and the amorphous fraction corresponds to $25-30 \%$. The addition of porphyrin therefore does not modify the phase repartition and it is possible to obtain high crystalline materials with a low temperature treatment $\left(\mathrm{T}^{\circ}<150{ }^{\circ} \mathrm{C}\right)$.

From Eq. (1), an estimated value of $\mathrm{TiO}_{2}$ crystallite size is calculated $(d$ XRD in Table 1$)$. The size of $\mathrm{TiO}_{2}$ crystallites is similar in all samples, between 4 and $6 \mathrm{~nm}$.

Table 1: Textural and optical properties of $\mathrm{TiO}_{2}$-based photocatalysts.

\begin{tabular}{lcccccc}
\hline Samples & $\begin{array}{c}S_{\mathrm{BET}} \\
\left(\mathrm{m}^{2} \mathrm{~g}^{-1}\right) \\
\pm 5\end{array}$ & $\begin{array}{c}V_{\mathrm{DR}} \\
\left(\mathrm{cm}^{3} \mathrm{~g}^{-1}\right) \\
\pm 0.01\end{array}$ & $\begin{array}{c}d_{\mathrm{XRD}} \\
(\mathrm{nm}) \\
\pm 1\end{array}$ & $\begin{array}{c}E_{\mathrm{g}, \text { direct }} \\
(\mathrm{eV}) \\
\pm 0.01\end{array}$ & $\begin{array}{c}D_{\text {PNP8 }} \text { under } \\
\text { UV/visible } \\
(\%)\end{array}$ & $\begin{array}{c}D_{\text {PNP24 }} \text { under } \\
\text { visible } \\
(\%)\end{array}$ \\
\hline $\mathrm{TiO}_{2}$ & 180 & 0.09 & 4 & 3.28 & 50 & \pm 3 \\
$\mathrm{TiO}_{2} / \mathrm{P} 1$ & 173 & 0.09 & 6 & - & 52 & 28 \\
$\mathrm{TiO}_{2} / \mathrm{P} 3$ & 180 & 0.09 & 5 & - & 55 & 35 \\
$\mathrm{TiO}_{2} / \mathrm{P6}$ & 178 & 0.09 & 5 & - & 61 & 65 \\
$\mathrm{TiO}_{2} / \mathrm{P} 6-$ & 178 & 0.09 & 4 & - & 51 & 30 \\
$\mathrm{Grafted}_{\mathrm{P} 25}$ & 55 & 0.02 & 22 & 3.16 & 80 & 12 \\
\hline
\end{tabular}

$S_{\mathrm{BET}}$ : specific surface area determined by the BET method; $V_{\mathrm{DR}}$ : specific micropore volume determined by the DubininRaduskevitch theory; $d_{\mathrm{XRD}}$ : mean diameter of $\mathrm{TiO}_{2}$ crystallites measured by the Scherrer method; $E_{g \text {,direct }}$ : the direct optical band-gap values calculated by using the transformed Kubelka-Munk function; $D_{\text {PNP8: }}$ the degradation percentage of PNP

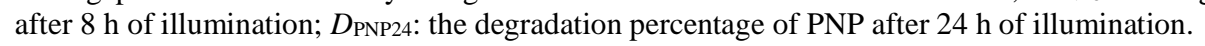

\subsubsection{Textural properties of $\mathrm{TiO}_{2}$ based catalysts}

The textural properties of the five materials are listed in Table 1 and the nitrogen adsorptiondesorption isotherms are presented in Fig. 3. 


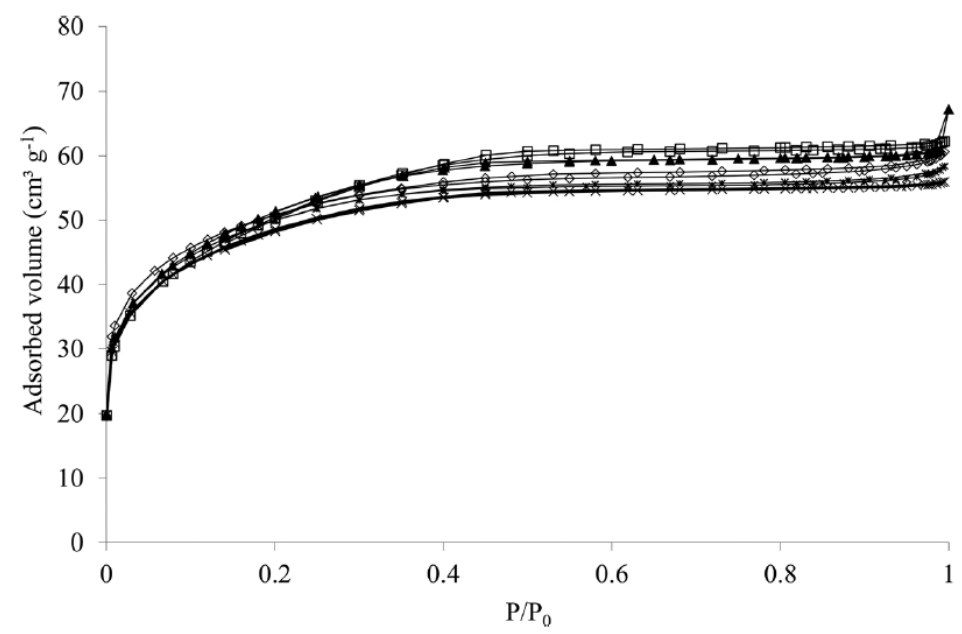

Fig. 3. Nitrogen adsorption-desorption isotherms of pure $\mathrm{TiO}_{2}(\boldsymbol{\Delta}), \mathrm{TiO}_{2} / \mathrm{P} 1(\square), \mathrm{TiO}_{2} / \mathrm{P} 3(\diamond), \mathrm{TiO}_{2} / \mathrm{P} 6$ $(\times)$ and $\mathrm{TiO}_{2}$ /P6-Grafted (*) samples.

All samples exhibit both isotherms of type I, characteristic of a microporous solid from the BDDT classification [63]. A sharp increase at low $p / p 0$ values followed by a plateau is observed, with $S_{\mathrm{BET}}$ values around $180 \mathrm{~m}^{2} \mathrm{~g}^{-1}$.

The addition of POR-Si has no influence on the textural properties of pure $\mathrm{TiO}_{2}$ materials.

\subsubsection{Optical properties of $\mathrm{TiO}_{2}$ based catalysts}

The UV/vis spectrum (Fig. 4) of an ethanolic solution of POR-Si shows absorption peaks at 425, 520, 558, 598 and $654 \mathrm{~nm}$ corresponding to the Q bands and Soret band of POR$\mathrm{Si}[73]$.

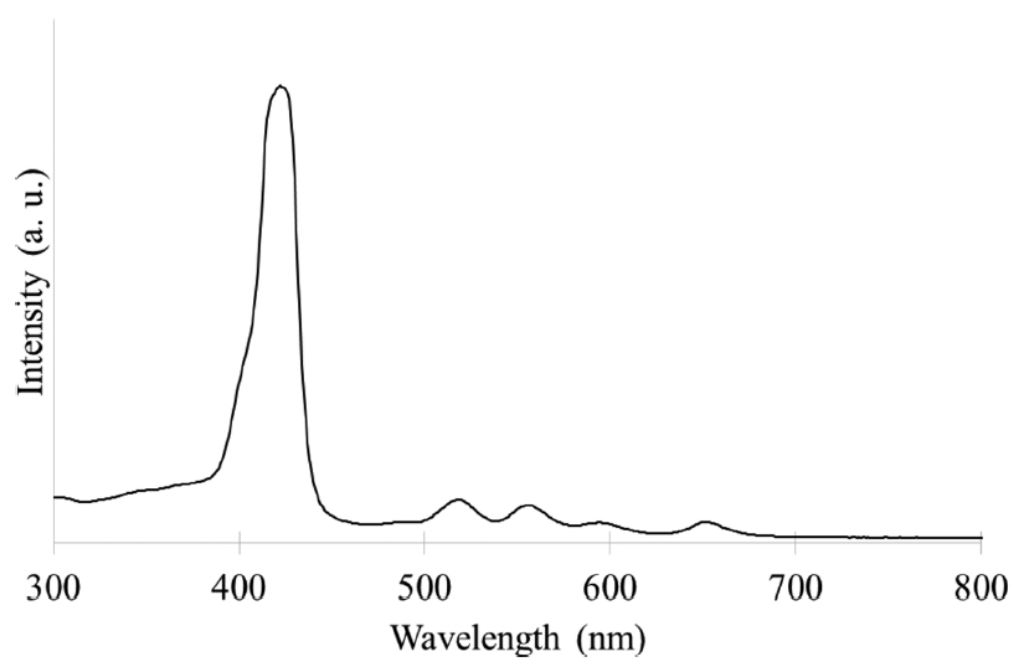

Fig. 4. UV/visible spectrum of an ethanolic solution of POR-Si.

The evolution of the normalized Kubelka-Munk function $\mathrm{F}(R \infty)$ with wavelength, $\lambda$, is presented in Fig. 5 for all the aqueous-made $\mathrm{TiO}_{2}$ materials. For pure $\mathrm{TiO}_{2}$, the maximum of absorption occurs in the UV region starting from $390 \mathrm{~nm}$, while for porphyrin-doped $\mathrm{TiO}_{2}$ samples absorption peaks are also observed in the visible region indicating the presence of 
porphyrin in the $\mathrm{TiO}_{2}$ material. The absorption peak intensities increase when the content of POR-Si increases in the samples (Fig. 5) from $\mathrm{TiO}_{2} / \mathrm{P} 1$ to $\mathrm{TiO}_{2} / \mathrm{P} 6$.

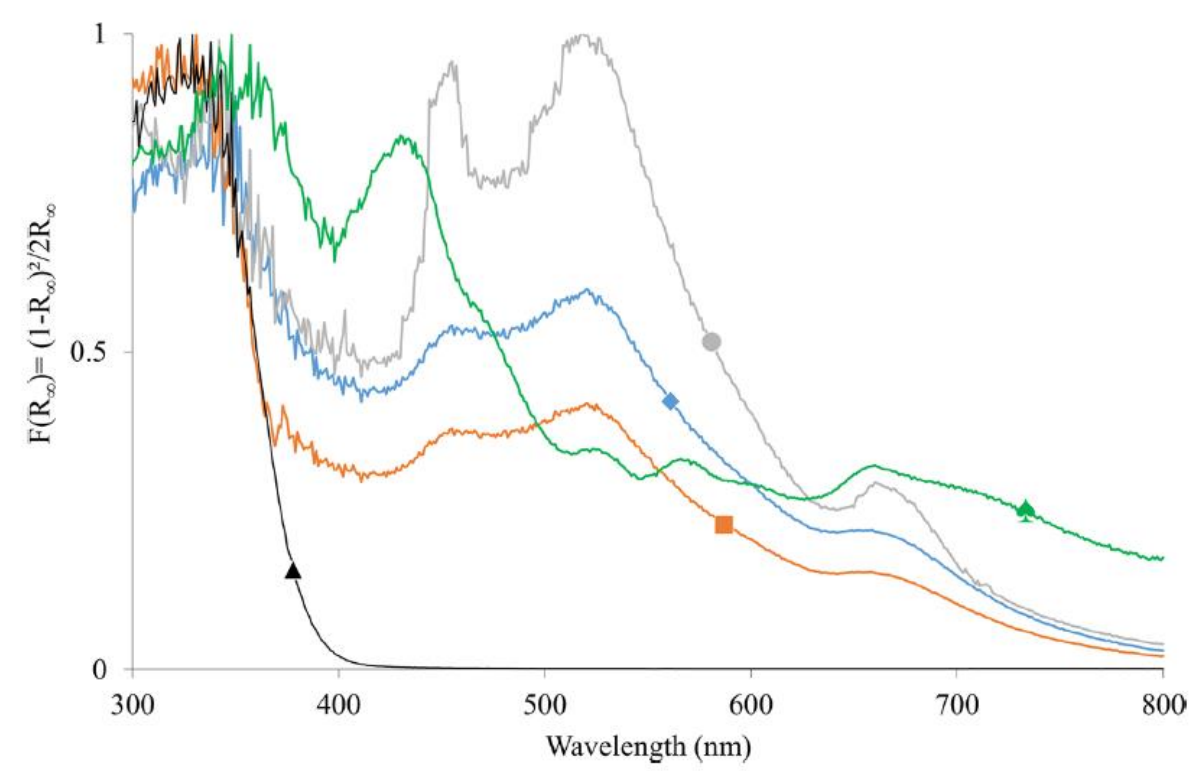

Fig. 5. Normalized Kubelka-Munk function $\mathrm{F}(R \infty)$ calculated from DR-UV-Vis spectra for pure $\mathrm{TiO}_{2}$ $(\boldsymbol{\Lambda}), \mathrm{TiO}_{2} / \mathrm{P} 1(\bullet), \mathrm{TiO}_{2} / \mathrm{P} 3(\bullet), \mathrm{TiO}_{2} / \mathrm{P} 6(\bullet)$ and $\mathrm{TiO}_{2} / \mathrm{P} 6-$ Grafted $(\bullet)$ samples.

For the grafted sample $\left(\mathrm{TiO}_{2} / \mathrm{P} 6-\right.$ Grafted), absorption in the visible range is also observed, but the absorption peak positions are different from those of doped samples. These are much more similar to the peaks observed from the POR-Si ethanolic solution (Fig. 4). These differences in absorption spectra can result from a different bonding between PORSi and $\mathrm{TiO}_{2}$. In the case of the $\mathrm{TiO}_{2} / \mathrm{P} 6-$ Grafted sample, POR-Si and $\mathrm{TiO}_{2}$ materials can be linked with TiO-C bonding as found in other cases [50,56-60], leading to a small modification of light absorption by the porphyrin, as observed previously [42,50]. The grafted sample absorption is quite high as the porphyrin is located only on the surface of $\mathrm{TiO}_{2}$, in contrast to the doped samples where porphyrin could be also anchored in the core of the material. This results from a different synthesis mode (grafting vs. cogelation). Moreover, macroscopically, the colors of the doped and grafted samples are different, violet and green respectively, obtaining different absorption spectra is therefore logical.

The direct and indirect band gaps are calculated for pure sample (Table 1) but it is not possible to calculate band gaps for porphyrindoped $\mathrm{TiO}_{2}$ samples due to their great absorption in visible region. This visible region absorption can indicate that this material will be efficient under visible light (see below photocatalytic Section 3.2.6.).

\subsubsection{FT-IR studies}

For all materials, the FT-IR spectra between 500 and $4000 \mathrm{~cm}^{-1}$ exhibit quite similar vibration peaks at $3300 \mathrm{~cm}^{-1}$ and between 1300 and $1700 \mathrm{~cm}^{-1}$, corresponding, respectively, to the vibration of hydroxyl groups and water molecules adsorbed on the $\mathrm{TiO}_{2}$ surface (Fig. 6) [42]. The FT-IR spectra for pure $\mathrm{TiO}_{2}, \mathrm{TiO}_{2} / \mathrm{P} 3$ and $\mathrm{TiO}_{2} / \mathrm{P} 6$ samples are represented in Fig. 6, but $\mathrm{TiO}_{2} / \mathrm{P} 1$ and $\mathrm{TiO}_{2} / \mathrm{P} 6-$ Grafted samples are not shown as their adsorption spectra are exactly the same as the pure $\mathrm{TiO}_{2}$ sample. 


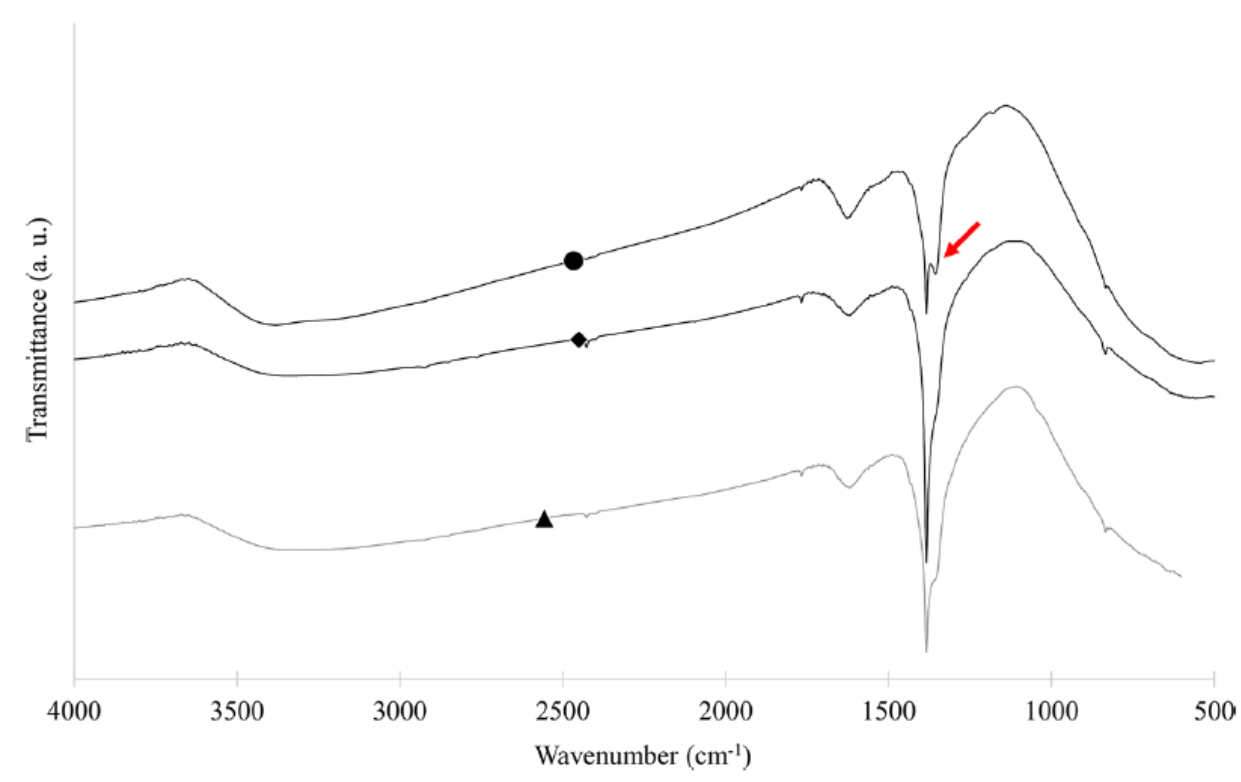

Fig. 6. FT-IR spectra for pure $\mathrm{TiO}_{2}(\boldsymbol{\Delta}), \mathrm{TiO}_{2} / \mathrm{P} 3(\bullet)$ and $\mathrm{TiO}_{2} / \mathrm{P} 6(\bullet)$ samples. Red arrow denotes the peak around $1370 \mathrm{~cm}^{-1}$ (For interpretation of the references to colour in this figure legend, the reader is referred to the web version of this article).

The pure $\mathrm{TiO}_{2}$ and $\mathrm{TiO}_{2} / \mathrm{P} 3$ FT-IR spectra present no appreciable differences owing to the low amount of POR-Si in the samples (molar ratio $\mathrm{POR}-\mathrm{Si} / \mathrm{TiO}_{2}$ equal to 0.003 ), no characteristic peak is observed on the FT-IR spectra, as previously reported with low concentrations of porphyrin $[42,73]$. For the $\mathrm{TiO}_{2} / \mathrm{P} 6$ sample, a peak around $1370 \mathrm{~cm}^{-1}$ can be observed which could correspond to the porphyrin. The FT-IR spectrum of POR-Si, which is represented in Fig. 7, presents the same peak at $1370 \mathrm{~cm}^{-1}$. In this case, the amount of POR-Si is the highest of the study and so could be detected with FTIR.

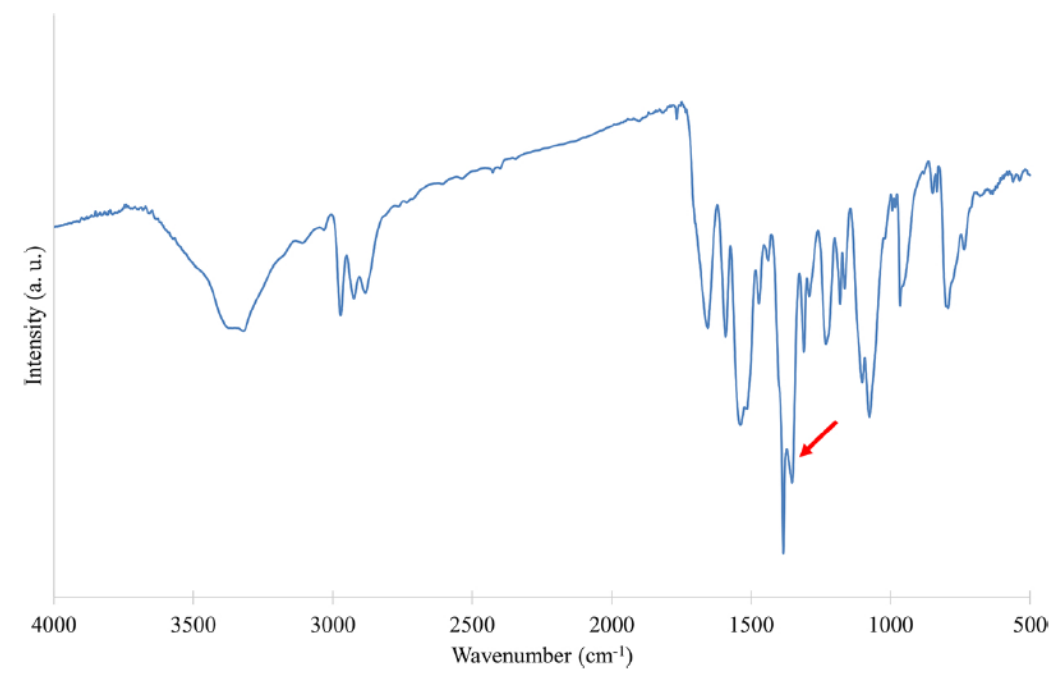

Fig. 7. FT-IR spectra for POR-Si material. Red arrow denotes the peak around $1370 \mathrm{~cm}^{-1}$ (For interpretation of the references to colour in this figure legend, the reader is referred to the web version of this article).

\subsubsection{Solid state NMR studies}

In our study, NMR measurement seems the most sensitive characterization to determine the bonding between $\mathrm{TiO}_{2}$ and porphyrin. 
The ${ }^{29} \mathrm{Si}$ CP-MAS solid state NMR experiments performed for PORSi, the porphyrindoped $\mathrm{TiO}_{2}$ samples and the grafted sample are presented in Fig. 8.

The relatively narrow lineshape observed for POR-Si indicates that the silicon environment is relatively crystalline, and the isotropic chemical shift at approximately $-47 \mathrm{ppm}$

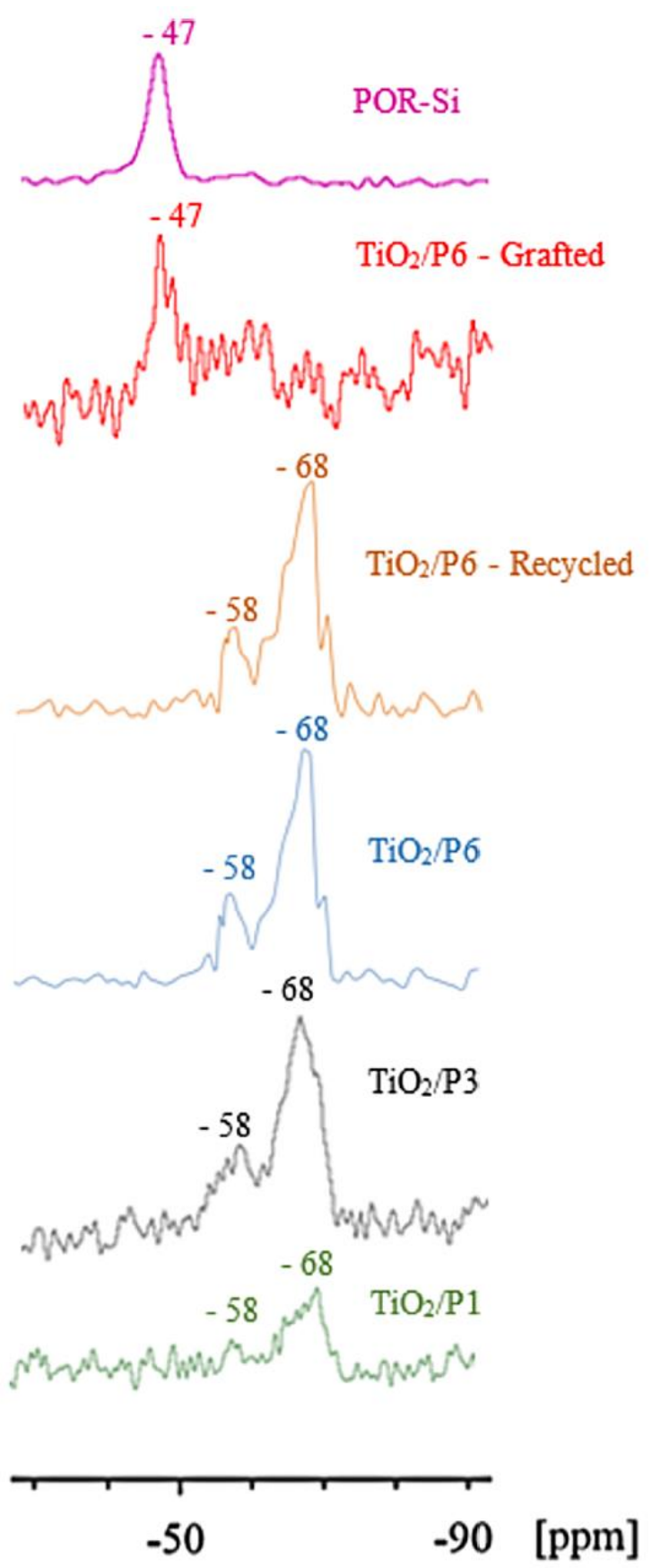

Fig. 8. ${ }^{29} \mathrm{Si} \mathrm{CPMAS}$ solid state NMR spectra of $\mathrm{POR}-\mathrm{Si}, \mathrm{TiO}_{2} / \mathrm{P} 1, \mathrm{TiO}_{2} / \mathrm{P} 3, \mathrm{TiO}_{2} / \mathrm{P} 6$,

$\mathrm{TiO}_{2} / \mathrm{P} 6-$ Recycled and $\mathrm{TiO}_{2} / \mathrm{P} 6-$ Grafted samples. is indicative of a $\mathrm{T}^{\circ}\left[\mathrm{RSi}(\mathrm{OEt})_{3}\right]$ silicon environment with no hydrolysis and no condensation

at the silicon $[74,75]$, where Tn denotes the rate of condensation at the silicon atom and where $\mathrm{R}$ denotes an organic group, corresponding in this case to the porphyrin core.

In contrast, the porphyrin-doped $\mathrm{TiO}_{2}$ sample spectra exhibit broad peaks at around $58 \mathrm{ppm}$ and $-68 \mathrm{ppm}$. The peak at $-58 \mathrm{ppm}$ corresponds to a $\mathrm{T}^{2}$ configuration silicon site [RSi(OEt)1(OTi $)_{2}$ ] [76] whereas the peak at $68 \mathrm{ppm}$ corresponds to a completely condensed $\mathrm{T}^{3}$ configuration [RSi $\left.(\mathrm{OTi})_{3}\right]$ [76,77]. The broadness of the chemical shifts indicates that the silicon is amorphous. This result demonstrates the incorporation of POR-Si in $\mathrm{TiO}_{2}$ and is typical in the aqueous pathway $\left(\mathrm{TiO}_{2} / \mathrm{Px}\right.$ samples). The signals for $\mathrm{Si}-\mathrm{O}-\mathrm{Ti}$ bonds seem to increase when the amount of POR-Si increases in the three samples.

For $\mathrm{TiO}_{2} / \mathrm{P} 6$-Grafted sample, it is noteworthy that the signal to noise ratio is significantly lower than the other doped $\mathrm{TiO}_{2}$ samples, indicating that the amount of silicon present is lowest in this sample. When the POR-Si is grafted, the ethanolic grafting solution is still colored after $48 \mathrm{~h}$ due to unreacted POR-Si, the grafted amount isprobably lower than the ratio $n P O R-S i / n T i O_{2}$ of 0.006 . The peak at $-47 \mathrm{ppm}$ is relatively narrow and is of a similar chemical shift to that of POR-Si, therefore this peak may be due to POR-Si chemisorbed on $\mathrm{TiO}_{2}$ with Ti-O-C bonding indicative of a $\mathrm{T}^{\circ}\left[\mathrm{RSi}(\mathrm{OC})_{3}\right]$ silicon environment [74].This bonding is observed with "classical" grafting of porphyrin on catalysts $[50,56-60]$.

\subsubsection{Photocatalytic activity}

The photocatalytic activity of the five materials is given in Table 1 and Fig. 9 after $24 \mathrm{~h}$ under low energy light ( $\left.D_{\text {PNP24 }}\right)$.

Pure $\mathrm{TiO}_{2}$ degrades $50 \%$ of PNP after $8 \mathrm{~h}$ under UV/visible light (Table 1). Compared to pure $\mathrm{TiO}_{2}$, porphyrin-doped $\mathrm{TiO}_{2}$ samples show a slightly enhanced activity under UV/visible light: $52 \%$ for $\mathrm{TiO}_{2} / \mathrm{P} 1,55 \%$ for $\mathrm{TiO}_{2} / \mathrm{P} 3,61 \%$ for $\mathrm{TiO}_{2} / \mathrm{P} 6$ and $51 \%$ for the 
$\mathrm{TiO}_{2} / \mathrm{P6}$-Grafted sample. These improvements are more striking under low energy light (Fig. 9), especially for the significantly increased photoactivity for $\mathrm{TiO}_{2} / \mathrm{P} 6$ of up to $65 \%$ compared to $20 \%$ for the porphyrin-free material (pure $\mathrm{TiO}_{2}$ sample). This result demonstrates the important role of the porphyrin fragment in the material which enhances catalytic degradation under visible light. The $\mathrm{TiO}_{2} / \mathrm{P} 6-$ Grafted sample has activity that is more similar to $\mathrm{TiO}_{2} / \mathrm{P} 1$ than $\mathrm{TiO}_{2} / \mathrm{P} 6$, probably due to the lower amount of POR-Si grafted on the $\mathrm{TiO}_{2}$ surface as observed with NMR measurements (Fig. 8).

The visible absorption observed in reflectance measurements (Fig. 5) is also demonstrated in the photocatalytic activity by the increased degradation under visible light compared to pure $\mathrm{TiO}_{2}$. Evonik P25 photocatalyst is also tested for the degradation of PNP under visible light, the degradation after $24 \mathrm{~h}$ is $12 \pm 3 \%$ (Fig. 9). This value is lower than the pure $\mathrm{TiO}_{2}$ sample (20\%). All the doped $\mathrm{TiO}_{2}$ samples are between two and six times better than the commercial product (Table 1).

With these results, the classical mechanism [67] of porphyrin on the photocatalytic process can be considered.

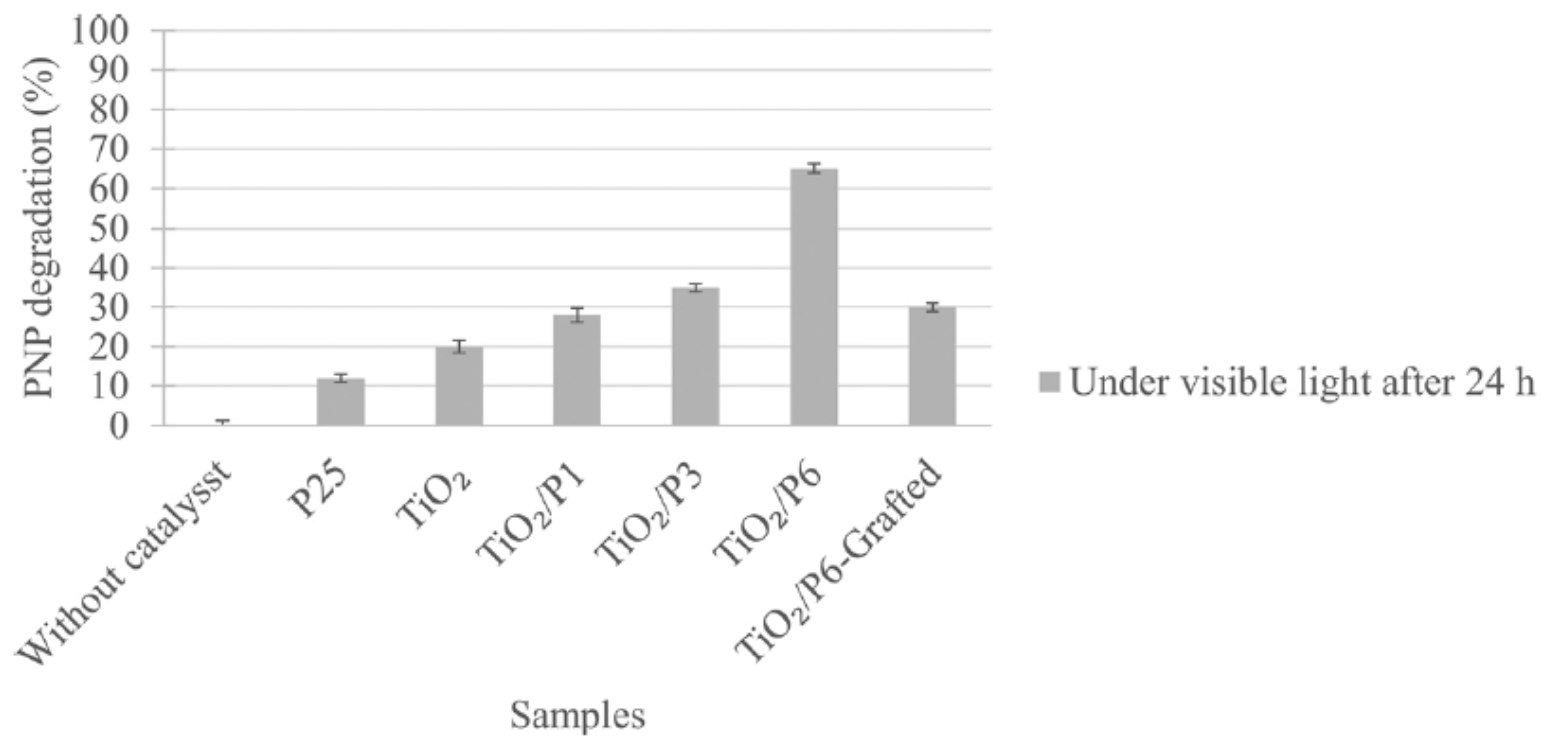

Fig. 9. PNP degradation (\%) without catalyst and for all the samples under visible light after $24 \mathrm{~h}$ of irradiation.

When the catalysts are exposed to UV/visible light, the main mechanism for PNP degradation is the classical $\mathrm{TiO}_{2}$ mechanism (Fig. 10) [67]. Irradiation allows the formation of electron-hole pairs $\left(\mathrm{e}^{--} \mathrm{h}+\right)$ in $\mathrm{TiO}_{2}$. The reactions with $\mathrm{O}_{2}$ and $\mathrm{H}_{2} \mathrm{O}$, generate $\% \mathrm{OH}$ and $\mathrm{O} 2 \%$ radicals which can degrade the organic pollutant. The irradiated porphyrin is excited, transferring electrons from the HOMO to LUMO level, these electrons can be transferred to the conduction band of $\mathrm{TiO}_{2}$ (Fig. 10) [44,50]. Bonds between POR-Si molecules and $\mathrm{TiO}_{2}$ particles are observed with ${ }^{29} \mathrm{Si}$ CPMAS NMR experiments (Fig. 8) but as the molar ratio of POR-Si/ $/ \mathrm{TiO}_{2}$ is very low (between 0.001 and 0.006 ), the amount of electrons transferred by the excited porphyrin remains negligible compared to those produced by the $\mathrm{TiO}_{2}$ itself, leading to a low increase in photoactivity. 


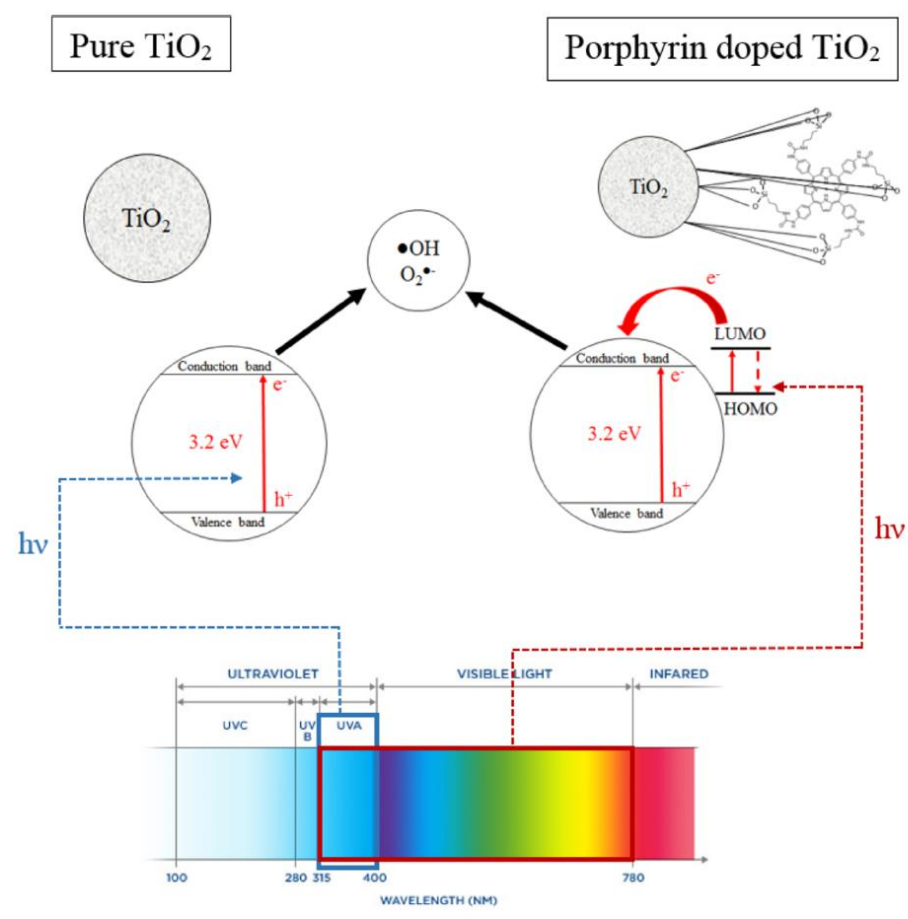

Fig. 10. Theoretical mechanisms of photocatalysis by the pure $\mathrm{TiO}_{2}$ sample and $\mathrm{TiO}_{2}$ doped with silylated porphyrin sample.

When only low energy light is used, the classical mechanism of $\mathrm{TiO}_{2}$ producing radicals is less efficient as only a low percentage of UV rays are present to activate $\mathrm{TiO}_{2}$ [67]. In this case, the porphyrin is still excited by the visible light and can thus transfer electrons towards $\mathrm{TiO}_{2}$, which are useful in order to produce additional radicals and offset the decrease of activity of $\mathrm{TiO}_{2}$ itself (Fig. 10).

\subsubsection{Durability and comparison with previous studies}

In order to show the stability of our samples, a durability study is made of the three doped catalysts and the grafted sample, with 11 consecutive photocatalytic tests which correspond to $264 \mathrm{~h}$ of operation (Fig. 11).

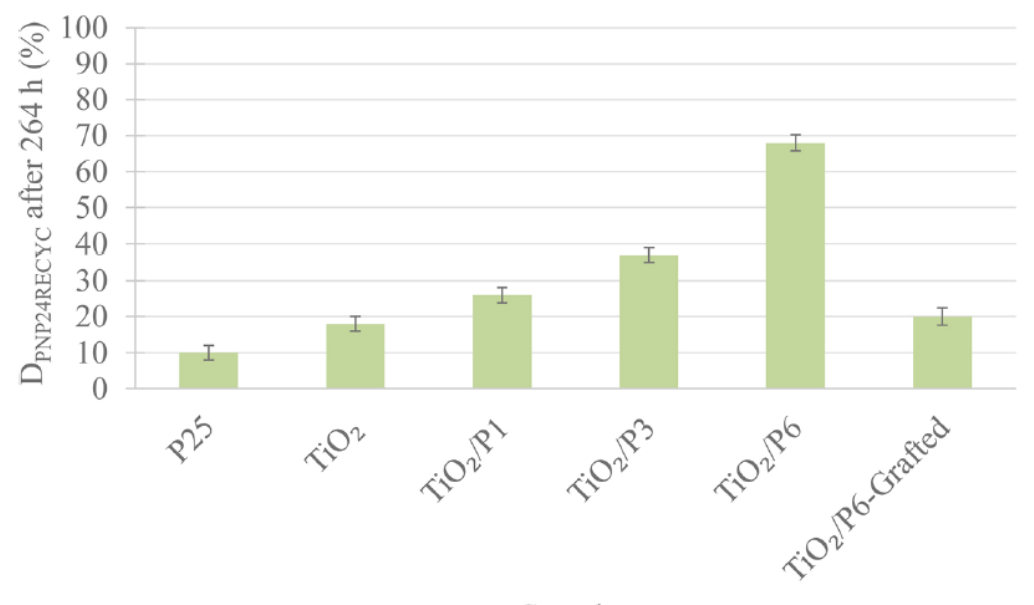

Samples

Fig. 11. Mean PNP degradation ( $D_{\mathrm{PNP} 24 \mathrm{RECYC}}$ in \%) under visible light for all samples after the ten recycling cycles (corresponding to 11 catalytic tests of $24 \mathrm{~h}$ each, with isolation of the sample and drying stages in between). 
In Fig. 11 and Table 1, $D_{\text {PNP24RECYC }}$ shows the mean PNP degradation for the pure $\mathrm{TiO}_{2}$, Evonik P25, grafted and porphyrin-doped $\mathrm{TiO}_{2}$ samples after the eleven photocatalytic cycles under visible light. For each doped sample, the activity stays stable over time. The mean PNP degradation values on recycling are the same as the values obtained on the first catalytic test (Table 1). The $\mathrm{TiO}_{2} / \mathrm{P} 6$ sample is characterized after the eleven cycles, the ${ }^{29} \mathrm{Si}$ NMR spectrum is presented in Fig. 8 and the diffuse reflectance spectroscopy measurement is exactly the same as its initial spectrum represented in Fig. 5.

This stability of photoactivity, the Si NMR measurement and the diffuse reflectance spectroscopy measurement of the $\mathrm{TiO}_{2} / \mathrm{P} 6$ recovered sample show that porphyrin stays attached to $\mathrm{TiO}_{2}$. Furthermore, the macroscopic color of the samples is identical through the different tests.

In contrast, the $\mathrm{TiO}_{2} / \mathrm{P} 6-$ Grafted sample shows a decrease of photocatalytic

activity which is similar to pure $\mathrm{TiO}_{2}$ activity after three cycles (Fig. 11 and Table 1). The catalyst sample loses its coloration after three photocatalytic cycles $(72 \mathrm{~h})$. In this case, the link between POR-Si and the $\mathrm{TiO}_{2}$ is broken and the porphyrin is probably removed with the washing step leading to an activity due to pure $\mathrm{TiO}_{2}$ only.

In this study, the porphyrin is more strongly linked to the $\mathrm{TiO}_{2}$ in doped samples than in other studies [40,51] due to the Si-O-Ti bond observed with NMR measurements. In a previous study, the porphyrin is found to be mainly linked to the $\mathrm{TiO}_{2}$ through $\mathrm{Ti}-\mathrm{O}-\mathrm{C}$ bonds [42,50,52] which are not stable during photocatalytic tests. In Min et al. [57], the photoactivity decreases after 10 cycles of only $3 \mathrm{~h}$ of photocatalysis, losing $40 \%$ of activity. In Chen et al. [59], after 6 cycles of 150 min of photocatalysis, the activity gradually decreases. In Yao et al. [78], the activity decreases by $10 \%$ after 5 cycles of $2 \mathrm{~h}$ of photocatalysis. In Cherian et al. [52] and Hyeon et al. [40], porphyrin desorption occurs over time. In numerous studies $[42,50,52,58,60]$, improvement in photoactivity is observed but no durability study was made. In these reports recycling tests are often missing.

In this paper, photocatalytic stability is shown for $264 \mathrm{~h}$ under visible light illumination for the doped samples, but not for the grafted one.

\section{Conclusions}

In summary, in an attempt to produce efficient sensitized $\mathrm{TiO}_{2}$ photocatalysts with no leaching of the sensitizer molecule, silylated phophyrin is cogelified with TTIP. To add Siporphyrin molecules directly into a $\mathrm{TiO}_{2}$ matrix during synthesis by the cogelation method, only a low temperature treatment is possible in order to avoid the degradation of porphyrin fragments. This is why aqueous synthesis is used to produce three porphyrin-doped $\mathrm{TiO}_{2}$ catalysts and the corresponding pure $\mathrm{TiO}_{2}$ for comparison. A grafted sample is made for comparison with classical grafting methods used in the literature.

For all syntheses, anatase-brookite $\mathrm{TiO}_{2}$ catalysts are obtained with a crystallite size around $5 \mathrm{~nm}$, even at low temperatures. For the porphyrin- doped $\mathrm{TiO}_{2}$ materials, the absorption spectra are modified leading to visible absorption of light. NMR measurements confirm the bonds between POR-Si and $\mathrm{TiO}_{2}$ in doped samples. The grafted sample clearly shows different bonding between POR-Si and $\mathrm{TiO}_{2}$.

Concerning the photoactivity of samples, the introduction of POR-Si in the material not only (slightly) increases the photoactivity under UV/visible illumination but it promotes the efficiency of the decomposition of PNP under low energy light. Porphyrin molecules are excited by the visible light and thus are capable of transferring electrons towards $\mathrm{TiO}_{2}$, which are used to produce additional radicals and offset the decrease of activity of $\mathrm{TiO}_{2}$ itself. Recycling tests show the stability of the photocatalytic activity of aqueous porphyrin doped $\mathrm{TiO}_{2}$ samples, 
which have no leaching of the porphyrin over $264 \mathrm{~h}$ of operation. The grafted sample shows a decrease of activity towards pure $\mathrm{TiO}_{2}$ activity due to bond breaking between POR-Si and $\mathrm{TiO}_{2}$.

In comparison with commercial Evonik P25 catalyst, the samples present better activity under visible light, especially for porphyrin doped catalysts which have a photoactivity 2-6 times higher than the commercial product.

\section{Acknowledgements}

S. D. L. and J. G. M. thank the Belgian National Funds for Scientific Research (F.R.S.-FNRS) respectively for her Associate Researcher position and for his financial support for a short stay at the Institut Charles Gerhardt Montpellier, Laboratoire Architectures Moléculaires et Matériaux Nanostructurés, in Montpellier, France. The authors are grateful to Prof. Dirk Poelman, from the University of Ghent, for diffuse reflectance spectroscopy measurements. The Ministère de la Région Wallonne Direction Générale des Technologies, de la Recherche et de l'Energie (DG06), the Fonds de Recherche Fondamentale Collective and the Fonds de Bay are gratefully acknowledged.

[1] M.A. Fox, M.T. Dulay, Heterogeneous Photocatalysis, Chem. Rev. 93 (1993) 341-357.

[2] K.C. Wilson, E. Manikandan, M.B. Ahamed, B.W. Mwakikunga, Nanocauliflower like structure of $\mathrm{CdS}$ thin film for solar cell photovoltaic applications : In situ tin doping by chemical bath deposition technique, J. Alloys Compd. 585 (2014) 555-560. doi:10.1016/j.jallcom.2013.09.185.

[3] K. Lokesh, K. Lokesh, G. Kavitha, E. Manikandan, G.K. Mani, K. Kaviyarasu, et al., Effective Ammonia Detection Using n- ZnO / p- NiO Heterostructured Nanofibers, IEEE Sens. J. 16 (2016) 2477-2483. doi:10.1109/JSEN.2016.2517085.

[4] E. Manikandan, V. Murugan, G. Kavitha, P. Babu, M. Maaza, Nano fl ower rod wirelike structures of dual metal ( $\mathrm{Al}$ and $\mathrm{Cr}$ ) doped $\mathrm{ZnO}$ thin fi lms : Structural, optical and electronic properties, Mater. Lett. 131 (2014) 225-228. doi:10.1016/j.matlet.2014.06.008.

[5] K. Nakata, T. Ochiai, T. Murakami, A. Fujishima, Electrochimica Acta Photoenergy conversion with $\mathrm{TiO} 2$ photocatalysis : New materials and recent applications, Electrochim. Acta. 84 (2012) 103-111. doi:10.1016/j.electacta.2012.03.035.

[6] A. Fujishima, K. Hashimoto, T. Watanabe, TiO2 Photocatalysis: Fundamentals and Applications, 1999.

[7] A. Fujishima, T.N. Rao, D.A. Tryk, Titanium dioxide photocatalysis, J. Photochem. Photobiol. C Photochem. Rev. 1 (2000) 1-21.

[8] A. Fujishima, X. Zhang, D.A. Tryk, $\mathrm{TiO}_{2}$ photocatalysis and related surface phenomena, Surf. Sci. Rep. 63 (2008) 515-582. doi:10.1016/j.surfrep.2008.10.001.

[9] K. Hou, B. Tian, F. Li, Z. Bian, C. Huang, Highly crystallized mesoporous TiO 2 films and their applications in dye sensitized solar cells, J. Mater. Chem. 2 (2005) 2414- 2420. doi:10.1039/b417465h.

[10] P. Periyat, N. Leyland, D.E. Mccormack, J. Colreavy, S.C. Pillai, Rapid microwave synthesis of mesoporous TiO2 for electrochromic displays †, J. Mater. Chem. (2010) 36503655. doi:10.1039/b924341k.

[11] J.M. Szeifert, J.M. Feckl, D. Fattakhova-rohlfing, Y. Liu, V. Kalousek, J. Rathousky, et al., Ultrasmall Titania Nanocrystals and Their Direct Assembly into Mesoporous Structures Showing Fast Lithium Insertion, J. Am. Chem. Soc. (2010) 12605-12611. 
[12] M.A. Rauf, S.S. Ashraf, Fundamental principles and application of heterogeneous photocatalytic degradation of dyes in solution, Chem. Eng. J. 151 (2009) 10-18. doi:10.1016/j.cej.2009.02.026.

[13] O. Carp, Photoinduced reactivity of titanium dioxide, Prog. Solid State Chem. 32 (2004) 33-177. doi:10.1016/j.progsolidstchem.2004.08.001.

[14] J.G. Mahy, G.L.-M. Leonard, S. Pirard, D. Wicky, A. Daniel, C. Archambeau, et al., Aqueous sol-gel synthesis and film deposition methods for the large-scale manufacture of coated steel with self-cleaning properties, J. Sol-Gel Sci. Technol. 81 (2017) 27-35. doi:10.1007/s10971-016-4020-5.

[15] A. Fujishima, K. Honda, Photolysis-decomposition of water at the surface of an irradiated semiconductor, Nature. 238 (1972) 37-38.

[16] D.F. Ollis, Photocatalytic purification and remediation of contaminated air and water, Comptes Rendus l'Académie Des Sci. 3 (2000) 405-411.

[17] G.L. Léonard, C.A. Pàez, A.E. Ramírez, J.G. Mahy, B. Heinrichs, Interactions between $\mathrm{Zn} 2+$ or $\mathrm{ZnO}$ with $\mathrm{TiO} 2$ to produce an efficient photocatalytic, superhydrophilic and aesthetic glass, J. Photochem. Photobiol. A Chem. $350 \quad$ (2018) 32-43. doi:10.1016/j.jphotochem.2017.09.036.

[18] Y. Ma, X. Wang, Y. Jia, X. Chen, H. Han, C. Li, Titanium Dioxide-Based Nanomaterials for Photocatalytic Fuel Generations, Chem. Rev. 114 (2014) 9987-10043.

[19] J. Schneider, M. Matsuoka, M. Takeuchi, J. Zhang, Y. Horiuchi, M. Anpo, et al., Understanding TiO2 Photocatalysis : Mechanisms and Materials, Chem. Rev. 114 (2014) 9919-9986.

[20] K. Nakata, A. Fujishima, Photochemistry Reviews TiO2 photocatalysis : Design and applications, J. Photochem. Photobiol. C Photochem. Rev. 13 (2012) 169-189. doi:10.1016/j.jphotochemrev.2012.06.001.

[21] G.L.-M. Léonard, C.M. Malengreaux, Q. Mélotte, S.D. Lambert, E. Bruneel, I. Van Driessche, et al., Doped sol-gel films vs. powders TiO2: On the positive effect induced by the presence of a substrate, J. Environ. Chem. Eng. 4 (2016) 449-459. doi:10.1016/j.jece.2015.11.040.

[22] B. Braconnier, C. a. Páez, S. Lambert, C. Alié, C. Henrist, D. Poelman, et al., Ag- and $\mathrm{SiO} 2$-doped porous $\mathrm{TiO} 2$ with enhanced thermal stability, Microporous Mesoporous Mater. 122 (2009) 247-254. doi:10.1016/j.micromeso.2009.03.007.

[23] C. Anderson, A.J. Bard, An Improved Photocatalyst of TiO2/SiO2 Prepared by a Sol-Gel Synthesis, J. Phys. Chem. 99 (1995) 9882-9885. doi:10.1021/j100024a033.

[24] M. Gratzel, Sol-gel processed TiO2 films for photovoltaic applications, J. Sol-Gel Sci. Technol. 22 (2001) 7-13. doi:10.1023/A:1011273700573.

[25] E. Bailon-Garcia, A. Elmouwahidi, M.A. Alvarez, F. Carrasco-Marin, A.F. PerezCadenas, F.J. Maldonado-Hodar, New carbon xerogel-TiO2 composites with high performance as visible-light photocatalysts for dye mineralization, Appl. Catal. B Environ. 201 (2017) 2940. doi:10.1016/j.apcatb.2016.08.015.

[26] R.R. Bacsa, J. Kiwi, Effect of rutile phase on the photocatalytic properties of nanocrystalline titania during the degradation of $\mathrm{p}$-coumaric acid, Appl. Catal. B Environ. 16 (1998) 19-29.

[27] C.M. Malengreaux, S. Douven, D. Poelman, B. Heinrichs, J.R. Bartlett, An ambient temperature aqueous sol-gel processing of efficient nanocrystalline doped TiO2-based photocatalysts for the degradation of organic pollutants, J. Sol-Gel Sci. Technol. (2014) 557570. doi:10.1007/s10971-014-3405-6.

[28] M. Pelaez, N.T. Nolan, S.C. Pillai, M.K. Seery, P. Falaras, A.G. Kontos, et al., A review on the visible light active titanium dioxide photocatalysts for environmental applications, Appl. Catal. B Environ. 125 (2012) 331-349. doi:10.1016/j.apcatb.2012.05.036. 
[29] C.J. Bodson, B. Heinrichs, L. Tasseroul, C. Bied, J.G. Mahy, M. Wong Chi Man, et al., Efficient P- and Ag-doped titania for the photocatalytic degradation of waste water organic pollutants, J. Alloys Compd. 682 (2016) 144-153. doi :10.1016/j.jallcom.2016.04.295.

[30] R. Asahi, T. Morikawa, H. Irie, T. Ohwaki, Nitrogen-Doped Titanium Dioxide as VisibleLight-Sensitive Photocatalyst : Designs, Developments , and Prospects, Chem. Rev. 114 (2014) 9824-9852.

[31] M.R. Hoffmann, S.T. Martin, W. Choi, D.W. Bahnemann, Environmental Applications of Semiconductor Photocatalysis, Chem. Rev. 95 (1995) 69-96. doi:10.1021/cr00033a004.

[32] A.L. Linsebigler, G. Lu, J.T. Yates, Photocatalysis on TiO2 Surfaces: Principles, Mechanisms, and Selected Results, Chem. Rev. 95 (1995) 735-758. doi:10.1021/cr00035a013. [33] G. Rossi, M. Calizzi, V. Di Cintio, S. Magkos, L. Amidani, L. Pasquini, et al., Local Structure of V Dopants in TiO2 Nanoparticles: X - ray Absorption Spectroscopy, Including Ab-Initio and Full Potential Simulations, J. Phys. Chem. C. 120 (2016) 7457-7466. doi:10.1021/acs.jpcc.5b12045.

[34] A. Di Paola, E. García-López, G. Marcì, L. Palmisano, A survey of photocatalytic materials for environmental remediation, J. Hazard. Mater. 211-212 (2012) 3-29. doi:10.1016/j.jhazmat.2011.11.050.

[35] R. Asahi, T. Morikawa, T. Ohwaki, K. Aoki, Y. Taga, Visible-Light Photocatalysis in Nitrogen-Doped Titanium Oxides, Science (80-. ). 293 (2001) 269-271.

[36] M. Harb, P. Sautet, P. Raybaud, Anionic or Cationic S - Doping in Bulk Anatase TiO2 : Insights on Optical Absorption from First Principles Clculations, J. Phys. Chem. C. 117 (2013) 8892-8902.

[37] N. Patel, A. Dashora, R. Jaiswal, R. Fernandes, M. Yadav, D.C. Kothari, et al., Experimental and Theoretical Investigations on the Activity and Stability of Substitutional and Interstitial Boron in TiO2 Photocatalyst, J. Phys. Chem. C. 119 (2015) 18581-18590. doi:10.1021/acs.jpcc.5b05290.

[38] J.G. Mahy, V. Cerfontaine, D. Poelman, F. Devred, E.M. Gaigneaux, B. Heinrichs, et al., Highly Efficient Low-Temperature N-Doped TiO 2 Catalysts for Visible Light Photocatalytic Applications, Materials (Basel). 11 (2018) 1-20. doi:10.3390/ma11040584.

[39] T. Wu, T. Lin, N. Serpone, TiO2 -Assisted Photodegradation of Dyes . Photooxidation of a Squarylium Cyanine Dye in Aqueous Dispersions under Visible Light Irradiation, Environ. Sci. Technol. 33 (1999) 1379-1387.

[40] C. Lee, T. Hyeon, H. Lee, Visible Light-Induced Degradation of Carbon Tetrachloride, Environ. Sci. Technol. 35 (2001) 966-970.

[41] G. Granados O., C.A. Páez M., F. Martínez O., E.A. Páez-Mozo, Photocatalytic degradation of phenol on $\mathrm{TiO} 2$ and $\mathrm{TiO} 2 / \mathrm{Pt}$ sensitized with metallophthalocyanines, Catal. Today. 107-108 (2005) 589-594. doi:10.1016/j.cattod.2005.07.021.

[42] L. Tasseroul, S.D. Lambert, D. Eskenazi, M. Amoura, C.A. Páez, S. Hiligsmann, et al., Degradation of $\mathrm{p}$-nitrophenol and bacteria with $\mathrm{TiO} 2$ xerogels sensitized in situ with tetra ( 4 -carboxyphenyl ) porphyrins, J. Photochem. Photobiol. A Chem. 272 (2013) 90-99. doi:10.1016/j.jphotochem.2013.08.023.

[43] G. Liu, W. Jaegermann, J. He, V. Sundstro, L. Sun, XPS and UPS Characterization of the TiO2/ZnPcGly Heterointerface: Alignment of Energy Levels, J. Phys. Chem. B. 106 (2002) 5814-5819.

[44] A. Kathiravan, R. Renganathan, S. Anandan, Electron transfer dynamics from the singlet and triplet excited states of meso-tetrakis ( $\mathrm{p}$-carboxyphenyl ) porphyrin into colloidal, J. Colloid Interface Sci. 348 (2010) 642-648. doi:10.1016/j.jcis.2010.05.002.

[45] J. Croissant, C. Mauriello-Jimenez, M. Maynadier, X. Cattoen, M. Wong Chi Man, L. Raehm, et al., Synthesis of disulfide-based biodegradable bridged silsesquioxane nanoparticles 
for two- photon imaging and therapy of cancer cells $\dagger$, Chem. Commun. 51 (2015) 1232412327. doi:10.1039/C5CC03736K.

[46] C. Mauriello-Jimenez, J. Croissant, M. Maynadier, X. Cattoen, M. Wong Chi Man, J. Vergnaud, et al., Porphyrin-functionalized mesoporous organosilica nanoparticles for twophoton imaging of cancer cells and drug delivery, J. Mater. Chem. B. 3 (2015) 3681-3684. doi:10.1039/C5TB00315F.

[47] S. Mandal, S.K. Nayak, S. Mallampalli, A. Patra, Surfactant-Assisted Porphyrin Based Hierarchical Nano/Micro Assemblies and Their E ffi cient Photocatalytic Behavior, Appl. Mater. Interfaces. 6 (2014) 130-136.

[48] I. Hod, O.K. Farha, J.T. Hupp, Powered by porphyrin packing, Nat. Publ. Gr. 14 (2015) 1192-1193. doi:10.1038/nmat4494.

[49] P. Battioni, E. Cardin, M. Louloudi, B. Schollhorn, G.A. Spyroulias, D. Mansuy, et al., Metalloporphyrinosilicas: a new class of hybrid organic-inorganic materials acting as selective biomimetic oxidation catalysts, Chem. Commun. 17 (1996) 2037-2038.

[50] L. Tasseroul, C.A. Páez, S.D. Lambert, D. Eskenazi, B. Heinrichs, Photocatalytic decomposition of hydrogen peroxide over nanoparticles of TiO 2 and $\mathrm{Ni}$ ( II ) - porphyrindoped TiO2 : A relationship between activity and porphyrin anchoring mode, "Applied Catal. B, Environ. 182 (2016) 405-413. doi:10.1016/j.apcatb.2015.09.042.

[51] G. Granados-Oliveros, E. Paez-Mozo, F. Martinez Ortega, C. Ferronato, J. Chovelon, Degradation of atrazine using metalloporphyrins supported on $\mathrm{TiO} 2$ under visible light irradiation, Appl. Catal. B Environ. 89 (2009) 448-454. doi:10.1016/j.apcatb.2009.01.001.

[52] S. Cherian, C.C. Wamser, Adsorption and Photoactivity of Tetra (4-carboxyphenyl) porphyrin ( TCPP ) on, J. Phys. Chem. B. 50 (2000) 3624-3629.

[53] L. Ye, R. Pelton, M.A. Brook, Biotinylation of TiO 2 Nanoparticles and Their Conjugation with Streptavidin, Langmuir. 29 (2007) 5630-5637.

[54] C.J. Bodson, S.D. Lambert, C. Alié, X. Cattoën, J. Pirard, C. Bied, et al., Effects of additives and solvents on the gel formation rate and on the texture of P- and Si-doped TiO2 materials, Microporous Mesoporous Mater. 134 (2010) 157-164. https://doi:10.1016/j.micromeso.2010.05.021.

[55] C.J. Bodson, S.L. Pirard, R. Pirard, L. Tasseroul, C. Bied, M. Wong Chi Man, et al., PDoped Titania Xerogels as Efficient UV-Visible Photocatalysts, J. Mater. Sci. Chem. Eng. 2 (2014) 17-32.

[56] C.A. Paez, S.D. Lambert, D. Poelman, J.P. Pirard, B. Heinrichs, Improvement in the methylene blue adsorption capacity and photocatalytic activity of H2-reduced rutile- $\mathrm{TiO} 2$ caused by $\mathrm{Ni}$ (II)porphyrin preadsorption, Appl. Catal. B Environ. 106 (2011) 220-227, https://doi.org/10.1016/j.apcatb.2011.05.029.

[57] K.S. Min, R.S. Kumar, J.H. Lee, K.S. Kim, S.G. Lee, Y.A. Son, Synthesis of new $\mathrm{TiO} 2 /$ porphyrin-based composites and photocatalytic studies on methylene blue degradation, Dyes Pigm. 160 (2019) 37-47, https://doi.org/10.1016/j.dyepig.2018. 07.045.

[58] M.A. Ahmed, Z.M. Abou-Gamra, H.A.A. Medien, M.A. Hamza, Effect of porphyrin on photocatalytic activity of $\mathrm{TiO} 2$ nanoparticles toward Rhodamine B photodegradation, J. Photochem. Photobiol. B Biol. 176 (2017) 25-35, doi : 10.1016/j.jphotobiol.2017.09.016.

[59] S. Chen, F. Shen, Novel substituted porphyrins: synthesis, characterization and photocatalytic activity of their TiO2-based composites, J. Incl. Phenom. Macrocycl. Chem. 88 (2017) 229-238, https://doi.org/10.1007/s10847-017-0724-6.

[60] L. Wang, S. Duan, P. Jin, H. She, J. Huang, Z. Lei, et al., Anchored Cu(II) tetra(4carboxylphenyl)porphyrin to $\mathrm{P} 25$ ( $\mathrm{TiO} 2$ ) for efficient photocatalytic ability in $\mathrm{CO} 2$ reduction, Appl. Catal. B Environ. 239 (2018) 599-608, https://doi.org/10.1016/j. apcatb.2018.08.007. [61] J.C. Biazzotto, O.A. Serra, Y. Iamamoto, Synthesis and properties of urea porphyrinosilica, J. Non. Solids 273 (2000) 186-192. 
[62] F. Lerouge, G. Cerveau, R.J.P. Corriu, C. Stern, R. Guilard, Self-organization of porphyrin units induced by magnetic field during sol - gel polymerization, Chem. Commun. 15 (2007) 1553-1555, https://doi.org/10.1039/b616421h.

[63] A. Lecloux, Exploitation des isothermes d'adsorption et de desorption d'azote pour l'etude de la texture des solides poreux, Memoires Societe R. Des Sci. Liege. (1971) 169-209.

[64] a.L. Patterson, The scherrer formula for X-Ray particle size determination, Phys. Rev. 56 (1939) 978-982, https://doi.org/10.1103/PhysRev.56.978.

[65] N. Doebelin, R. Kleeberg, Profex: a graphical user interface for the Rietveld refinement program BGMN, J. Appl. Crystallogr. 48 (2015) 1573-1580, doi: 10.1107/S1600576715014685.

[66] I.C. Madsen, R.J. Finney, R.C.A. Flann, M.T. Frost, B.W. Wilson, Quantitative analysis of high-alumina refractories using X-ray powder diffraction data and the rietveld method, $\mathrm{J}$. Am. Ceram. Soc. 74 (1991) 619-624.

[67] J.G. Mahy, S.D. Lambert, G.L.-M. Leonard, A. Zubiaur, P.-Y. Olu, A. Mahmoud, et al., Towards a large scale aqueous sol-gel synthesis of doped TiO2: study of various metallic dopings for the photocatalytic degradation of p-nitrophenol, J. Photochem. Photobiol. A: Chem. 329 (2016) 189-202, https://doi.org/10.1016/j.jphotochem.2016.06.029.

[68] P. KUBELKA, Ein Beitrag zur Optik der Farban striche, Z. Tech. Phys. 12 (1931) 593603 (accessed October 16, 2015), http://ci.nii.ac.jp/naid/10008164867/en/.

[69] P. Kubelka, New contributions to the optics of intensely light-scattering materials, J. Opt. Soc. Am. 38 (1948) 448-457, https://doi.org/10.1364/JOSA.44.000330.

[70] Ca. Paez, D. Poelman, J.P. Pirard, B. Heinrichs, Unpredictable photocatalytic ability of $\mathrm{H} 2$-reduced rutile-TiO2 xerogel in the degradation of dye-pollutants under $\mathrm{UV}$ and visible light irradiation, Appl. Catal. B Environ. 94 (2010) 263-271, doi:.1016/j.apcatb.2009.11.017.

[71] A. Escobedo Morales, E. Sanchez Mora, U. Pal, Use of diffuse reflectance spectroscopy for optical characterization of un-supported nanostructures, Rev. Mex. Fis. S. 53 (2007) 18-22 http://www.researchgate.net/publication/229050010_Use_of_diffuse_reflectance_spectroscop y_for_optical_characterization_of_unsupported_nanostructures/file/79e41507eead49bb27.pdf [72] C.A. Paez, D.Y. Liquet, C. Calberg, S.D. Lambert, I. Willems, A. Germeau, et al., Study of photocatalytic decomposition of hydrogen peroxide over ramsdellite- $\mathrm{MnO} 2$ by O2-pressure monitoring, Catal. Commun. 15 (2011) 132-136, doi :10.1016/j.catcom.2011.08.025.

[73] L. Tasseroul, S.L. Pirard, S.D. Lambert, Ca. Paez, D. Poelman, J.P. Pirard, et al., Kinetic study of p-nitrophenol photodegradation with modified TiO 2 xerogels, Chem. Eng. J. 191 (2012) 441-450, https://doi.org/10.1016/j.cej.2012.02.050.

[74] S. Cerneaux, S.M. Zakeeruddin, J.M. Pringle, Y.B. Cheng, M. Gratzel, L. Spiccia, Novel nano-structured silica-based electrolytes containing quaternary ammonium iodide moieties, Adv. Funct. Mater. 17 (2007) 3200-3206, https://doi.org/10. 1002/adfm.200700391.

[75] R.J.P. Corriu, J.J.E. Moreau, P. Thepot, New mixed organic-inorganic polymers: hydrolysis and polycondensation of bis ( $\mathrm{t}$ rimet hoxysilyl) organometallic precursors, Chem. Mater. 4 (1992) 1217-1224.

[76] Y.-J. Chan, B.-G. Kum, Y.-C. Park, E.-H. Kong, H.M. Jang, Surface modification of TiO2 nanoparticles with phenyltrimethoxysilane in dye-sensitized solar cells, Bull. Korean Chem. Soc. 35 (2014) 415-418, https://doi.org/10.5012/bkcs.2014.35.2.415.

[77] R.H. Glaser, G.L. Wilkes, C.E. Bronnimann, Solid-state 29Si NMR of TEOS-based multifunctional sol-gel materials, J. Non. Solids 113 (1989) 73-87.

[78] B. Yao, C. Peng, W. Zhang, Q. Zhang, J. Niu, J. Zhao, A novel Fe(III) porphyrinconjugated TiO2visible-light photocatalyst, Appl. Catal. B Environ. 174-175 (2015) 77-84, https://doi.org/10.1016/j.apcatb.2015.02.030. 